\title{
Appraisal of Shipping Trade Influence on Economic Growth in Nigeria
}

\author{
Ikpechukwu Njoku* Olowolagba Lateef Yomi Olisa Babatope Sunday \\ Department of Transport Management Technology, Federal University of Technology Akure, Nigeria
}

\begin{abstract}
The study examined appraisal of shipping trade influence on the economic growth in Nigeria from 1981-2016 by the use of secondary data collected from the Central Bank of Nigeria. The main objectives are to examine the trend of shipping trade in Nigeria as well as determine the influence of economic growth on gross domestic product (GDP). The study employed both descriptive and influential tools. The study adopted cointegration regression method for the analysis of each of the variables (shipping trade, external reserves and external debts). The results show that there is a statistically significant relationship between GDP and external reserves with p-value 0.0190 . Also the result revealed that there is a statistically significant relationship between GDP and shipping trade with p-value 0.000 . However, shipping trade and external reserves contributed positively at $1 \%$ and $5 \%$ level of significance respectively while external debts impacted negatively to GDP at $5 \%$ level of significance with a long run variance of cointegration regression. Therefore, the study suggests that government should do all it can to curtail foreign dominance and repatriation of profit for a more sustainable economy as well as upgrade port facilities, prevent unnecessary delays and encourage exportable goods for maximum deployment of ships.
\end{abstract}

Keywords: External debts, External reserve, GDP and Shipping trade.

DOI: $10.7176 / \mathrm{CER} / 12-1-04$

Publication date: January $31^{\text {st }} 2020$

\section{Introduction}

Foreign trade is concern with the exchange of goods and services between nations. This exchange of goods and services can either take the form of imports or exports. International trade, therefore, causes goods to move through international boundaries, usually through land borders, seaports and airports (Ofobrukweta, 2001). But it is not every trade that moves through the borders, as there are two forms of trade, namely: visible trade and invisible trade. Visible trade is the exchange of goods, which are seen physically passing through the borders of both the importing countries and the exporting countries. Invisible trade on the other hand, involves the exchange of services, which are not physically seen. They include shipping, insurance, banking, tourism, freight forwarding and technical skills. The demand for goods and services, which are available in other countries, arises when a country is unable to meet the demand of its citizens in terms of raw materials, finished goods and services (Ofobrukweta, 2001).

Nigeria is heavily dependent on imports of machinery and raw materials for the survival of its industries. There is also high demand for foodstuff and food related goods such as rice, grains and sugar. The importation of these and other goods has increased over the years with the gradual removal of import restrictions on most goods. Nigeria involves in multi-lateral trading which provides means of existence in terms of work, eat and earn income for itself as a nation. All these collaborations could be made possible through shipping (Ofobrukweta, 2001).

Shipping has for a long time been recognised as one of the string catalysts for socio-economic development. The process of navigating or engaging in commerce through various types of navigable waters introduces the related concept of shipping. Shipping involves the art of transporting goods, often termed cargo, from one point to another on any stretch of water. Shipping business can be said to be one of the oldest businesses in the world. Historically, it constitutes a major source of political power and territorial influence for " he who rules the sea, rules the world " Mukherjee (2010). Shipping transportation plays a very significant role in the consolidation of global markets. However, shipping industry is not a single industry; it can be divided into sub-sectors which differ depending on the usefulness and usability offered in the labour market. The main segmentation separates shipping according to its purpose. At first, shipping is divided in passenger shipping, merchant shipping and maritime of special purposes (Vasilopoulos, 2013).

The passenger shipping applies to transportation of people with vessels which can transport more than 12 passengers (Durand, 2014). Depending on the particular circumstances prevalent in some areas, the more significant categories are Ferry Boats, Cruises and Dolphins (Flying Cats Vessels). Ships of this class can offer accommodation to the passengers and transportation to vehicles (cars or trucks) and have the ability to develop very high speeds in relation to the ships of Merchant Navy. (Marin, 2011) The second and most important category is the commercial vessel which is related solely to the movement of goods. Such goods may include raw materials, semi-manufactured materials and or finished products. Finally, the third category refers to the vessels of special purposes which is also worth mentioning in comparison to the previous categories. Ideal examples for this specific category are the auxiliary vessels in ports (tugs, boats or speedboat, sailboats) as well as vessels that serve under 
specific conditions such as icebreakers (United Nations Conference on Trade and Development, 2007).

Shipping based on classification by commodities could either be charter party which is known as "One ship one cargo basis" or the general cargo line shipping market known as "One ship many different cargoes basis" (United Nations Conference on Trade and Development, 2007). Shipping as primary logistics provider is critical in the process of Nigerian's international trade and economic development. As a mode of transport, shipping provides the cheapest and most efficient means of moving large volumes of import and export round the world thereby creating jobs and adding value to the economy (Ma, 2011).

\subsection{Statement of Problems}

Nigeria is characterized by significant debt burden, structural imbalance and uncertainties which resulted to declining productivity. There are three major factors that influence the development of shipping industry in Nigeria; they are lack of capital, poor incentives for investors, poor integrated transport system.

Shipping is highly capital intensive. Nigeria, with a very low capital formation, makes it difficult if not impossible to mobilize the needed capital for investment in shipping. More so, investment in shipping does not yield quick returns especially as Nigerian investors do not have access to foreign guaranteed loans due to lack of suitable collateral. This makes it difficult for indigenous shipping companies to acquire ships through loan finance from the ship yards.

Modern shipping is highly sophisticated and capital intensive. To this extent, shipping has very high commercial risk. That is why the traditional maritime countries accord shipping very favourable and attractive investment incentives (Ekpo, 2012). In Nigeria, shipping is not accorded similar concessionary fiscal and monetary incentives like countries in developed maritime nations. For example, the tax rate applicable to shipping in Nigeria is the same as other businesses. Shipping is not accorded any concessions and it is neither classified as a "pioneer" industry nor does it fallwithin "agro" industries that enjoy tax free holidays. Under these harsh conditions, investors would prefer less risky businesses.

Integrated transport is the transportation of goods under a single contract, but performed with at least two or three different means of transport. The carrier is liable for the entire carriage, though performed by several modes of transport (rail, sea, air, and road). The carrier does not need to possess all the means of transport (Muller, 2011). It is also known as combined transport. Integrated transport is an organ through which logistics supply chain management can function effectively. The legal infrastructure needs to be developed for intermodal transport to be meaningful. There are series of international legislation that affects intermodal transport, but full Implementation has always been a problem in Nigeria.

\subsection{Aim and Objectives of Study}

The aim of the study is to appraise shipping trade influence on economic growth in Nigeria while its objectives are to:

1) examine the trend of shipping trade in Nigeria and

2) determine the influence of the economic variables (shipping trade, external debts and external reserves) on gross domestic product.

\subsection{Research Hypothesis $H_{0}$}

$\mathrm{H}_{0}$ : There is no significant relationship between GDP and Shipping trade, external reserve and external debts payment

\section{Literature Review}

Economic growth from the early period of economic history engaged the attention of man and his governments. As far back as 17th and 18th centuries writers like Adam Smith, David Richardo, John Stuart Mill, as well as Karl Marx, Friedrich List, Karl Bucher, W. Rostow, and neoclassical economists such as Arthur Lewis (1978) have been preoccupied with the quest for economic growth.

The term economic growth is described as the positive and sustained increase in aggregate goods and services produced in an economy within a given time period. When measured with the population of a given country, then economic growth can be stated in terms of per capital income according to which the aggregate production of goods and services in a given year is divided by the population of the country in the given period. The framework for understanding growth over the long-term is rooted in two main theories that relates to possible sources of growth. These are the growth theory and the growth accounting theory. Growth theory is concerned with the theoretical modelling of the interactions among growth of factor supplies, savings, and capital formation, while growth accounting theory addresses the qualification of the contribution of the different determinants of growth.

Three waves of interest have currently emerged in studying economic growth. The first wave is associated with the work of Harrods (1900-1978) and Domar (1914-1997) in what was termed the "Harrods - Domar Model". The theory presupposed that growth depends on a country's saving rate, capital / output ratio, and capital 
depreciation. This theory has been criticised for three reasons. Firstly, it centers on the assumption of exogenecity for all key parameters. Secondly, it ignores technical change and lastly, it does not allow for diminishing returns when one factor expands relative to another (Woodford 2000) and (Essien 2002).

The second began with the neoclassical (Solow) model, which contained the thinking that growth reflected technical progress and key inputs, (Labour and capital). It allowed for diminishing returns, perfect competition but not externalities. In the neoclassical growth process, savings were needed to increase capital stock, capital accumulation had limits to ensure diminishing marginal returns and capital per unit of labour was limited. It postulates that growth also depended on population growth rate and that growth rate amongst countries was supposed to converge to a steady state in the long-run. Despite the modification, the basic problems associated with the neoclassical thinking are that it hardly explains the sources of technical change (Essien and Bawa, 2007).

The third is the newer alternative growth theory, which entrances a diverse body of theoretical and empirical work that emerged in the 1980s. This is "endogenous" growth theory. This theory distinguished itself from the neo classical growth model by emphasizing that economic growth was an outcome of an economic system and not the result of forces that impinged from outside. Its central idea was that the proximate causes of economic growth were the effort to economize, the accumulation of knowledge, and the accumulation of capital. According to this theory, anything that enhances economic efficiency is also good for growth. It entails capacity building which has an effect on policy formulation and implementation. Examining the future of Nigeria maritime industry, Nigeria requires a well-articulated maritime law and policy formulated to encourage and foster economic growth and development. Nigeria is on a global level which provides a horde of opportunities for investment to stimulate import and export trade by way of providing surface transport through which goods are moved by sea on a massive scale. Maritime business has helped the process of diversification of Nigerian's economy and has continued to provide employment opportunities to Nigerians as crew staff, mariners and dock workers in addition to various practitioners among which are freight forwarders. The economic status of any shipping operation will be determined by the relative levels of costs (capital and operating) and revenues. The demand and freight rates which determine revenues are presently increased in all shipping sectors thereby given the global nature of the shipping business that changes in market which tends to affect all operators. Shipping is a complex industry segmented into several markets differentiated by ship type, trade requirements, organisation and geographical location. Basically, shipping has the great potential to open up Africa markets and accelerate the pace of socio-economic development. Growth in international trade would stimulate a boom in the maritime and allied logistic sectors of economies of Africa Countries.

Indeed, since the arrival of Johnl d' Averino, the Portuguese explorer at the Benin River in 1485, trading contract by sea had been established between the Europeans and the West African Sub region and Nigeria in particular. The obnoxious trade in Africa, the slave trade would have been on small scale it was carried out but for the usage of sea routes by ship. Shipping made it possible for the colonialist to establish a firm hold in settler economies such as the South Africa where in 1627 the Dutch explorer Jan Van Riebea and his successors ensured that the natives continue to serve as cheap labour in mines and plantation.

Nevertheless, maritime (shipping trade) has played a major role in Nigerian economic development. Besides, it has also acted as a cardinal force in Nigeria to correct her trade imbalances with the industrialized nations of the world. Indeed, since becoming a signatory to the UNCTAD code for liner conference in 1975, a number of bilateral and multilateral maritime agreements have been entered into by the Nigerian Government and this to a large extent has aided the sector in the movement of cargo in and out of the Nigerian shores. In fact, the Nigerian National Shipping Line (NNSL) had not only provided employment to Nigerians but also served as a pool of training ground for majority of the master mariners and other experienced professional people in Nigeria's maritime sector. The need for adequate training and re-training of personnel for industry also culminated in the establishment of the Maritime Academy of Nigeria (MAN) at Oron and Nigerian Maritime University at Okerenkoko.

Shipping generates much needed foreign exchange to the Nigerian economy. This is in form of ship repairs, levies, taxes, port fees and charges among others. The Niger-dock for example though has not been known to have built an ocean-going vessel, but has been meaningfully engaged in the repairs and maintenance of ships and construction of ferry boats all of which constitute an integral part of maritime transport. Besides, it is official policy of the Nigerian Maritime Administrative and Safety Agency (NIMASA) to collect a levy on the gross freight from any vessel that calls at Nigerian ports for export and import purposes. The rationale behind this is to boost Nigerian merchant shipping fleet for the sake of effective lifting of her cargo. Since 1958, when oil was discovered in commercial quantity in Oloibiri, Nigeria's oil terminal such as Bonny, Escravos and Forcados have continued to play host to oil tankers of various profile and sizes. Though, Nigeria's external reserves buoyed the economy, the total exclusion of Nigeria's indigenous carriers from the lucrative trade has been a subject of debate between maritime practitioners and the federal government.

Shipping has provided opportunity for inland water way transport, coastal and high sea trading and has also made it possible for Nigerians to develop skill for fish and shrimps trawling enterprise. In a word, shipping has engendered employment for sizeable number of Nigerian in various maritime related occupations. It has accounted 
for the urbanization and industrialization of the nation as well as given a boost to Nigeria's trade and commercial relation with the outside world. Over the years, Shipping has been given commentaries in Nigeria. Most of these works are focused on selected and diverse aspect of maritime practice as it affects the growth. We have such central theme relating to the role of NIMASA. Shipping in Nigeria is an attendant growth in trade which provides the stimuli for African maritime nations to growth and develop their economies. Sectors such as ship owning, ship management, ship brokerage, ship finance, maritime insurance, maritime law and arbitration, maritime training and education would experience some boom. Other sectors that can be targeted include inland transport networks (Road, Rail, Inland waterways and pipelines), Port management and operations of warehousing, freight forwarding and distribution. Improvements in these sectors will enhance the competitiveness of African exports and accelerate the integration of African economy into global economy.

\section{Empirical Review and Research Gaps}

Many studies have been conducted on shipping trade and some economic growth but little attempts have been made in check the co-integration relationship between GDP and Nigeria economic growth like shipping trade, external reserve and external debts. A work-done by Christiana and Matthew (2013), they studied whether Maritime Transport Sector impacted on the Growth of Nigeria's Economy. The study analysed the effect of the Nigerian maritime sector on the growth of the Nigerian economy especially the industrial sector of the economy. The method of ordinary least square and the seemingly unrelated regression was used to estimate the impact of this key sector. They used a secondary data culled from CBN statistical bulletin. After analysing using a regression analysis, he found out that the maritime transport sector has a negative relationship, that is not significant on the economic growth of the nation and on industrialization of the Nigerian economy and concluded that the Nigerian maritime transport to have a positive and significant impact on economic growth and industrialization in Nigeria, government should formulate policies that would encourage genuine foreign and private participations in the maritime sector of the economy. The study by Christiana and Matthew (2013) finds the relationship between a sector in GDP and some Nigeria's economy growth using OLS regression analysis but our study uses all the sectors in GDP for a cointegration regression.

Usman and Ibrahim (2010) investigated the impact of change in external reserve positions of Nigeria on domestic investment, inflation rate and exchange rate. Using a combination of ordinary least square (OLS) and vector error correction (VEC) methods, it was observed that change in external reserves in the country only influences foreign direct investment (FDI) and exchange rates and no influence of it was found on domestic investment and inflation rates. The results suggest that there is the need for broader reserve management strategies that will aim at maximizing the gains from oil export revenue by utilizing more of these resources to boost domestic investment. This research considered external reserve as a dependent variable over exchange rate and foreign direct investment. In our study, external reserve was considered as an independent variable since it is one of the major factors of gross domestic product.

The study of Adeleye et. al, (2015) examines the impact of international trade on economic growth in Nigeria, using net export (i.e total export less total import) and Balance of Payment as proxies for international trade while Gross Domestic Product represent economic growth. The study employed regression analysis as the method of analysis using co-integration and error correction modelling techniques to find the long-run relationship between economic performance and international trade. However, Ijirshar et. al, (2016) examined the relationship between external debt and economic growth in Nigeria for the period of 1981-2014. The study used both descriptive and econometric tools. The analysis of unit root was performed on each of the variables incorporated in the model and the result showed that, all the variables were not stationary at level but achieved stationary after first difference at $5 \%$ level of significance. The regression results showed a significant relationship between external debt and economic growth in Nigeria. However, external debt stock impacted positively while external debt service impacted negatively on the annual growth rate of the Nigerian economy both in the long run and the short run. The study also considered external debts as dependents variable over some economic growth in Nigeria while we considered external debt as an independent variable in conjunction with some independent variables. In spite of the literature review, no previous work has actually gone extra mile of attempting to bridge the yawning gab among the maritime regulatory agencies in Nigeria such as the Nigerian Ports Authority (NPA), Nigerian shippers' council, Niger Dock and NIMASA among others to the effect of making them functional and capable of appraising shipping trade in Nigeria to international standards. Nigeria possesses the geo-political and demographic potentials of a major power, yet the industry continues to suffer degradation. Hence, this study is significant.

\section{Methodology}

4.1 Type of Data and Sources:

This study employed secondary sources of data which were obtained from the following sources: Central Bank of Nigeria (CBN Publications and Statistical Bulletin- Annual reports and statement of Accounts, Economic and financial reviews); Research Seminar papers and National Bureau of Statistics-Annual Abstract of Statistics. 


\subsection{Methods of Data Analysis}

The hypothesis formulated was analysed using cointegration regression and trend analysis. This is in view of multiple explanatory variables (shipping trade, external debts and external reserves) involved in each of the hypothesis of the study while long-run variance was used to determine the variability in the explanatory variables over the dependent variable.

Table 1. Data Analysis Procedure

\begin{tabular}{lllll}
\hline S/N & OBJECTIVES & DATA & DATA & ANALYSIS \\
& & REQUIRED & TECHNIQUES & \\
\hline 1 & $\begin{array}{l}\text { Examine the trend of shipping trade in Nigeria; } \\
\text { Determine the influence of the economic } \\
\text { variables (shipping trade, external debts and }\end{array}$ & $\begin{array}{l}\text { Secondary data } \\
\text { Secondary data }\end{array}$ & $\begin{array}{l}\text { Trend Analysis } \\
\text { Cointegration }\end{array}$ & Regression \\
& & Analysis &
\end{tabular}
external reserves) on gross domestic product.

Source: Author's Computation, (2019)

\subsection{Cointegration Regression Analysis}

The concepts of cointegration was according to Harris, (1995), who stated that if two (or more) series are linked to form an equilibrium relationship spanning the long run, then even though the series themselves may contain stochastic trend and thus be non-stationary, they will nevertheless move closely together over time and the difference between them will be stable (that is, stationary).

A linear combination of any two (or more) time series $\mathrm{y}_{\mathrm{t}}$ and $\mathrm{x}_{\mathrm{t}}$ 's is formed and each integrated at a lag order of 1 . However, if there are $n>2$ variables in the model, there may be more than one cointegration vector. It is possible for up to $\mathrm{n}-1$ linearly independent cointegration vector to exist, which has implications for testing and estimating cointegration relationships. Multivariate estimation technique was therefore used to detect all the possible long-run cointegration relationships present in the economic data.

The formula for cointegration regression analysis is designated as follows:

where;

$$
\mathrm{Y}_{\mathrm{t}}=\alpha_{0 \mathrm{t}}+\beta_{1} \mathrm{X}_{\mathrm{t}-1}+\beta_{2} \mathrm{X}_{\mathrm{t}-1}+\beta_{3} \mathrm{X}_{\mathrm{t}-1}+\mathrm{e}_{\mathrm{i}}
$$

$Y_{t}$ - Gross Domestic Product (1981 - 2016);

$\alpha_{0 t}$ - constant or the regression intercept;

$\beta_{1,-}$ is the coefficient of the independent variable, shipping trade;

$\beta_{2}$ - is the coefficient of the independent variable, external debts;

$\beta_{3}$ - is the coefficient of the independent variable, external reserves;

$\mathrm{X}_{\mathrm{t}-1}$ 's are the economic growth (that is, the independent variables which are shipping trade, external debts and external reserves) and;

$\mathrm{e}_{\mathrm{i}}-$ error term or the random error .

Therefore, the model would be:

$$
\mathrm{GDP}_{\mathrm{t}}=\text { constant }+\beta_{1}(\text { Shipping trade })_{\mathrm{t}-1}+\beta_{2}(\text { External debts })_{\mathrm{t}-1}+\beta_{3}(\text { External reserves })_{\mathrm{t}-1}+\mathrm{e}_{\mathrm{i}}
$$

\subsection{Test of Significance criteria}

The next stage after establishing economic growth criteria of the model is to develop the statistical and econometric criteria for the evaluation of the parameter estimate. Those adopted for this model includes; The $\mathrm{R}$ square of the correlation coefficient $\left(\mathrm{R}^{2}\right)$ is the ratio of explained variation to the total variation, which is offered called the coefficient of determination. It is used to show the percentage of total variation i.e. dependent variable that are explained by the independent variable. The ratio lies between 0 and 1 and the nearer to 1 , the greater the explanatory power of estimator.

Testing helps in deciding whether the estimates are significantly different or not. If the standard error of the regression is small than the half of the numerical value of the parameter estimates, we conclude that the estimates are statistically significant. In order to determine the goodness of fit of the regression line and reliability of the result, the quantitative tools such as adjusted coefficient of determination $\left(\mathrm{R}^{2}\right)$ and long-run variance were also employed.

Adjusted Coefficient of Determination $\left(\mathrm{R}^{2}\right)$ : owing to the fact that does not take into account the loss of degree of freedom, the adjusted would be used to measure the goodness of fit of the model.

Long-run variance: is a measure of the standard error of the sample mean when there is serial dependence.

\section{Results and Discussion}

\subsection{The Sectors in GDP}

Study revealed that four out of the Five (5) sectors in GDP that were considered in the study remained constant without rising between 1981 to 1993 while Construction remained constant to somewhere around 2007. Shipping trade is one of the major capitals and/or Inland water trade which has tremendous impact on the nation's economy 
and this is considered as the major aspect of gross domestic product. Figure 5.1 indicates that Shipping trade, Agriculture and industry moved in-line with each other though there was a little difference from the sectors. Agricultural, industrial and shipping sectors followed the same pattern which implies that they are more likely to have the same amount of domestic input in the country's GDP. These three (3) sectors rose from 1993 till 2016. Services tend to rise higher than the other sectors in GDP. It rose from 1993 till 2016 and it showed a rapid increment.

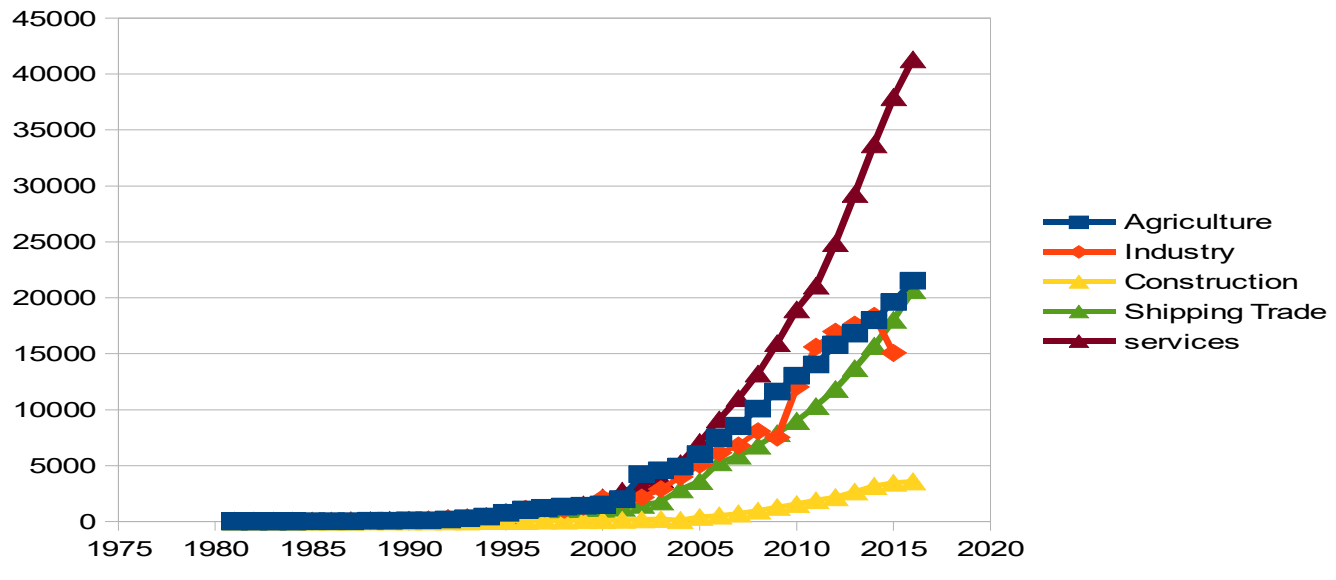

Figure 1: The graph of each sector in GDP

\subsection{GDP against Shipping Trade}

Figure 5.2 shows there is a linear relationship between the shipping trade and GDP with a total variability of $6 \%$ and a constant value of 2.649. This can be inferred that shipping trade remains constant for a period of 5 years and thereafter, increased.

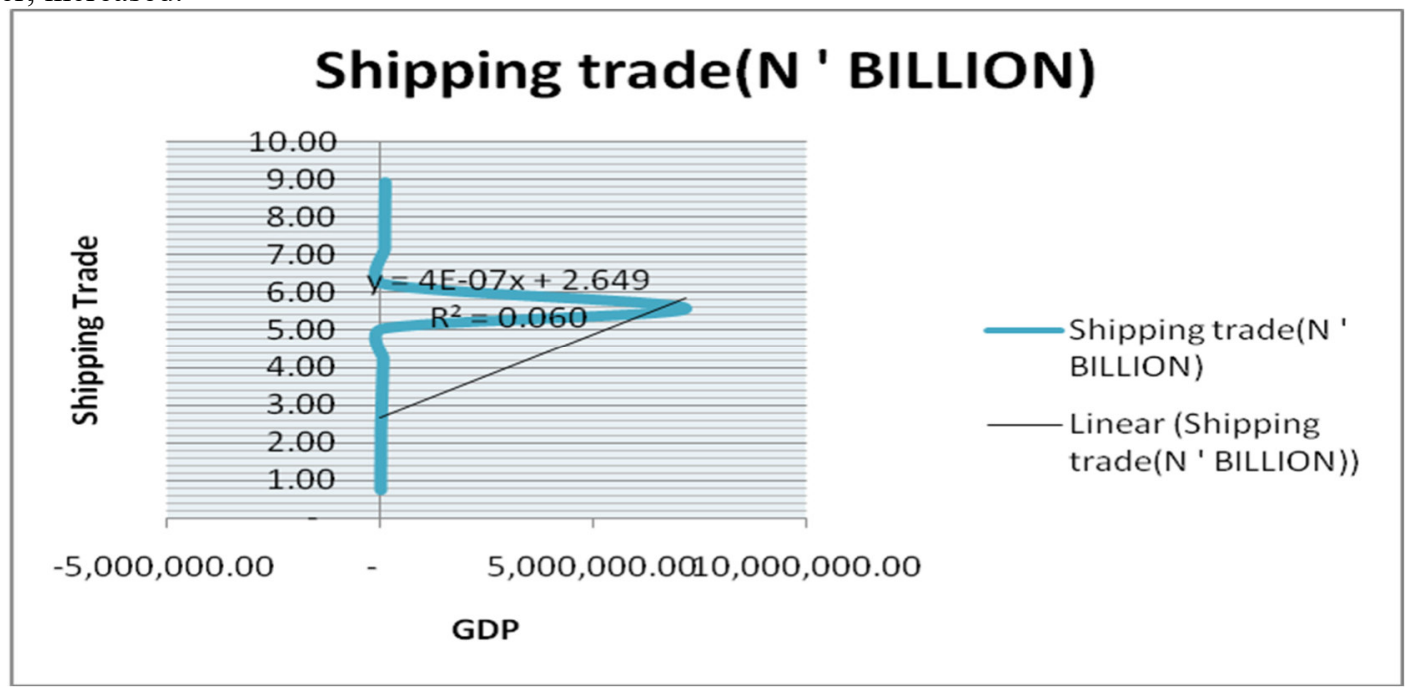

Figure 2. The graph of shipping trade against GDP

\subsection{Shipping Trade and External Reserve}

Study revealed that shipping trade and external reserves had remained constant for 18 years precisely between 1981 and 1999. From 1999, there was a rapid increase in the external reserve. Though, external reserve varied for some period of years till 2015 but it later had an increased in 2016. As shown in Figure 5.3, this implies that external reserve seemed to be varied in Nigeria's economic growth and development than shipping trade. The fluctuation of external reserve from 1999 and the increase in both import and export trade make it imperative to determine how shipping trade influenced Nigeria's external reserve. 


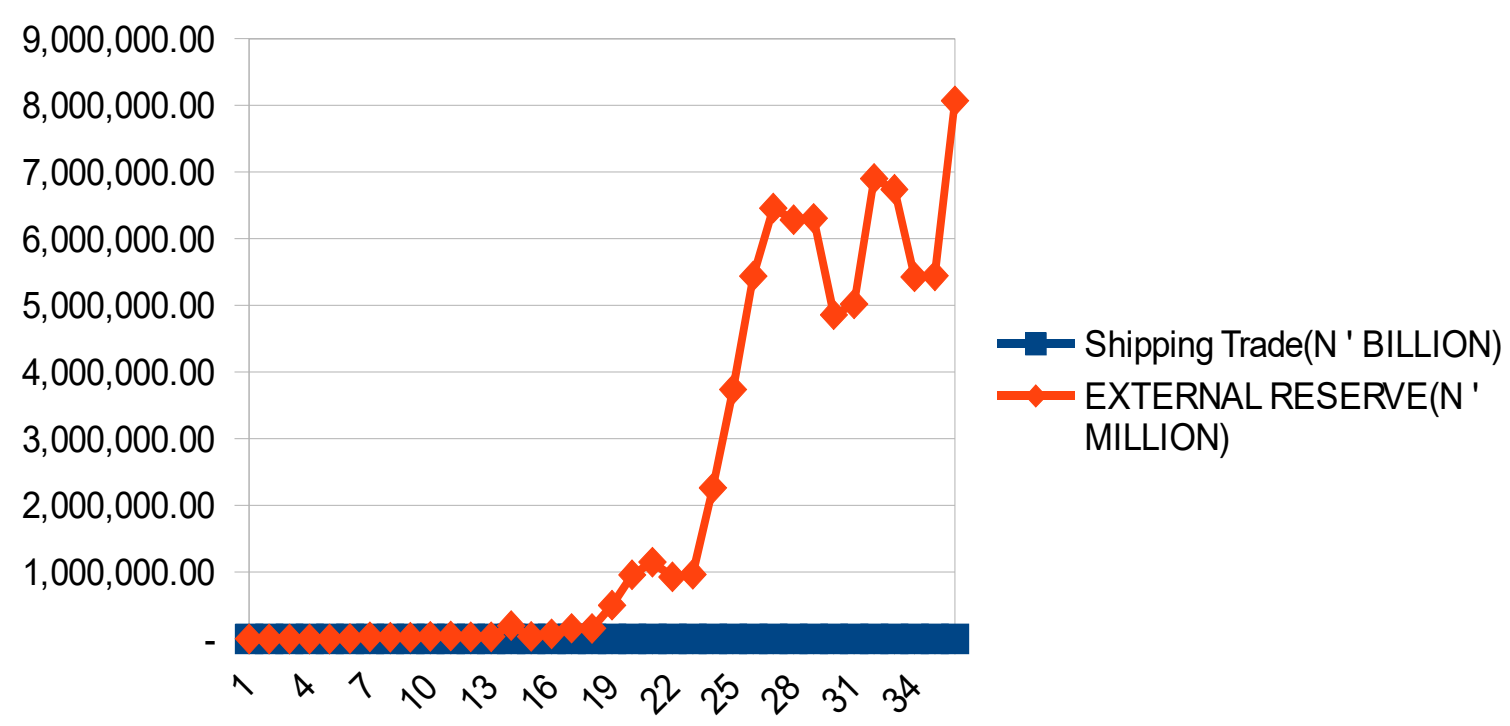

Figure 3. The graph of shipping trade and external reserve

5.4 Shipping Trade and External Debts

Shipping trade remains constant for a considerable number of years while, External debts payment remains constant for a period of 7 years (1981-1988) as indicated in Figure 5.4. From 1989, there was a little increment in external debts payment compared to shipping trade while in 1995; a sharp increment in the external debt payment of Nigeria was noticed until 2001 when it drops downward. This implies that external debt is found to be a driver of economic growth if properly managed but its servicing rather than repayment is an inhibiting factor to economic growth. External debts stand as mechanism where a nation's debt stock and the servicing arrangement (in term of shipping trade) do not cause severe problems for the economy and society at large.

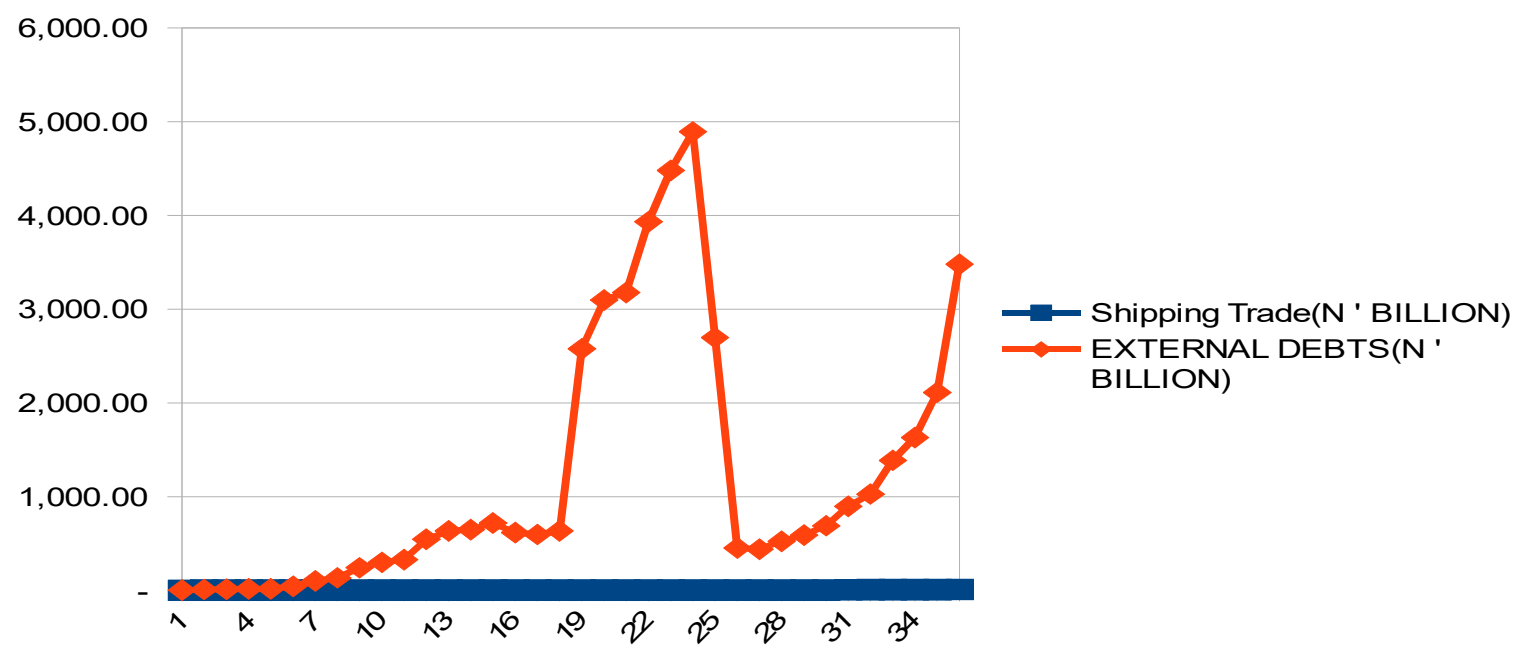

Figure 4. The graph of shipping trade against external debts payment

5.5 Examination of Trend of Shipping Trade in Nigeria between 1981-2016

Shipping trade is considered as life blood of the global economy, without shipping, the bulk of raw materials and the import/export of affordable goods would simply not be possible.

This section examined the trend of shipping trade before and after concessioning to determine any significant difference in the change of administration as presented in the trend analysis.

As shown in Figure 5.5, between 1981 and 1991 the trend of shipping trade was constant. Subsequently, the rate of using the shipping trade from the trend analysis indicated below demonstrated an arithmetic progression from 1991 to 2005. Consequent upon reform policy which enabled public private partnership in the year 2006, the trend of shipping trade in Nigeria from the year 2006 to 2016 experienced geometric progression. This achievement could be attributed to better coordination and improved efficiency. In conclusion, the decision of government to enable public private partnership has started yielding positive results. 


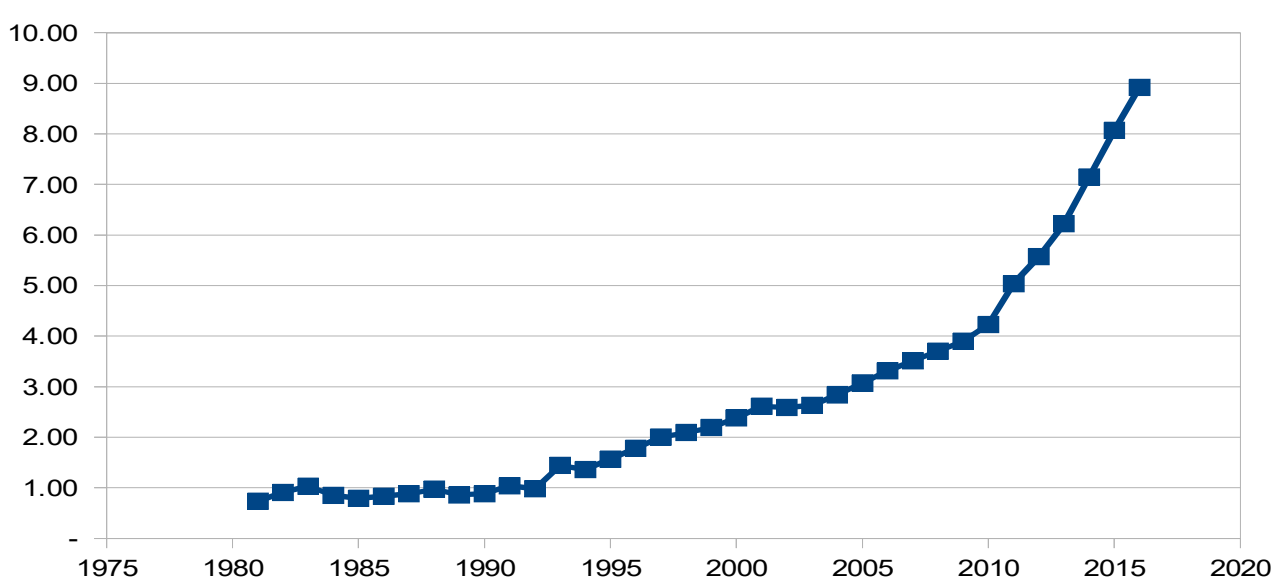

Figure 5. The trend analysis of shipping trade from $1981-2016$

5.6 Influence of the Economic variables on gross domestic product.

The Table 5.1 displays the cointegration result of the model. The adjusted $\mathrm{R}$ square signified that $97.97 \%$ of the economic variables (Shipping trade, external reserve and external debts) had been explained by the economic variables in GDP. The value of the adjusted R square (0.9797) gives the model a good fit. According to the standard error of regression obtained, all the explanatory variable are statistically significant in explaining the cointegration relationship on the appraisal of shipping trade on economic growth in Nigeria, through GDP, and are of the expected signs, which is in conformity with the theoretical expectation.

From the analysis, the study inferred that external reserve had a long-run relationship with GDP with a coefficient of 2.279231 and a probability value of 0.0190 . This implies that there was a stable and long-run relationship between GDP and shipping trade. Although, external debts was also significant to the GDP but there was a negative long-run relationship of -2.257741 between GDP and external debts with a p-value $<5 \%$ level of significance (0.0226). Shipping was considered as part of the economic variables; hence, there was a long run relationship between GDP and shipping trade with a coefficient of 14164.72 at $1 \%$ level of significant $(0.000)$. All the economic variables tend to be significant with GDP and there were stable and long run relationship between GDP and all the independent variables considered.

Therefore, the estimated cointegration regression model can be formulated as follows:

GDP $=-10891.46+2.279231$ (external reserve) -2.257741 (external debts) +14164.72 (Shipping trade)

Table 2. Cointegration Regression Analysis Output

Dependent Variable: GDP

Method: Fully Modified Least Squares (FMOLS)

Date: 08/16/19 Time: 03:10

Sample (adjusted): 19822016

Included observations: 35 after adjustments

Cointegrating equation deterministics: C @TREND

Long-run covariance estimate (Bartlett kernel, Newey-West fixed bandwidth $=4.0000)$

\begin{tabular}{|lllll|}
\hline \hline Variable & Coefficient & Std. Error & t-Statistic & Prob. \\
\hline \hline EXTERNAL_RESERVE & 2.279231 & 0.919189 & 2.479611 & 0.0190 \\
EXTERNAL_DEBTS & -2.257741 & 0.939519 & -2.403082 & 0.0226 \\
SHIPPING & 14164.72 & 1091.212 & 12.98073 & 0.0000 \\
C & -10891.46 & 2548.807 & -4.273159 & 0.0002 \\
$@$ TREND & -458.7093 & 284.2163 & -1.613944 & 0.1170 \\
\hline \hline R-squared & 0.982077 & Mean dependent var & 23029.06 \\
Adjusted R-squared & 0.979688 & S.D. dependent var & 31507.40 \\
S.E. of regression & 4490.461 & Sum squared resid & $6.05 E+08$ \\
Long-run variance & 29729348 & & \\
\hline \hline
\end{tabular}

Source: Author's Computation, (2019) 


\section{Discussion of Findings}

This study was carried out to investigate the appraisal of shipping trade on economic growth in Nigeria. The regression analysis result shows that the constant in the model is positively related to GDP and also significant.

External reserve and shipping trade are positively related to GDP, this conforms to a prior expectation while external debt payment is negatively related to GDP. The objective of the coefficient factors $\beta_{i}$ 's is the partial influence of $\mathrm{X}_{\mathrm{n}}$ on $\mathrm{Y}$, this means that the objective of the coefficient is the partial influence of the independent variables on the dependent variable. Therefore, this cointegration regression indicates that a 1 percent increase in the value of external reserve will result in a 2.28 percent increase in GDP at 5\% level of significance. However, this implies that external reserve contributes positively to GDP and it is said to be one of the determinants of GDP. This finding is consistent with the result of Usman and Ibrahim (2010) in Nigeria, which shows that external reserve has a positive relationship with GDP and it is significant.

For shipping trade, a rise in shipping trade by 1 percent will also amount to increase of GDP by 14164.72 . This shows a highly positive relationship and contribution between GDP and shipping trade with a p-value $<0.01$ (that is, 1\% level of significance) and it could be shown that there is a statistically significant cointegration relationship between GDP and Shipping trade.

However, a rise in 1 percent in external debts would result to a decrease in GDP by -2.26 . This depicts that there is negative relationship / contribution between GDP and external debts even though there is a statistically significant cointegration relationship between GDP and external debts with a p-value $<0.05$ (that is, $5 \%$ level of significance). This is in line with a study done by ijirshar et.al, (2016), where external debt payment is also significant and there is a negative relationship between external debts and some economic growth. Although, the aforementioned variables are significant both at $1 \%$ and $5 \%$ level of significance, this means that the external reserve, external debt and shipping trade are the part of the major variables that determine GDP in Nigeria. Economic growth is measured by the Gross Domestic Product (GDP) in Nigeria. GDP is a total market value of a country's output of goods and services, which are exchanged for money or traded in a market system over certain period. This indicates that trade is an essential aspect of Economic growth.

The trend and pattern of shipping trade tend to suggest that Nigeria is moving from a mono-cultural agrarian economy to a more diversified economy. The illusion in that hope, however, became apparent with the observation that expansion in exports till date was singularly accounted for by shipping trade and GDP, especially in the yearly increases of the trade and how it tends to increase over years. Nigeria has evidently benefitted from shipping trade over the past half a century. But the gains could have been greater if the economy and the production structures had been responsive and more readily adaptable to changing internal and external signals from the international economic system. In a constantly changing and highly competitive 58 global environment, Nigeria needs to continually re-examine and evaluate the sources of their strengths and weaknesses in order to devise appropriate policy strategies that could lead to maximum national benefits within the context of identified constraints.

\section{Summary of Findings}

The trend analysis on the shipping trade in Nigeria from 1981-2016 was positive and this can be attributed to the reform policies which enables public, private partnerships that led to concessioning of Nigerian ports since 2006 . The analysis on cointegration regression analysis was also ascertained between GDP and economic growths. This was established by the probability value ( $p$-value) $<0.05$ at $5 \%$ level of significance. Hence, the study established that there is a linear trend between the dependent variable and the explanatory variables.

\section{Conclusion}

Appraisal of shipping trade on economic growth in Nigeria was carried out covering thirty-six years (1981-2016) of operations of Nigerian ports with indicators of economic growth such as: gross domestic product, external reserves and external debts payments. Trend analysis for the same period was also examined. Consequently, it could be deduced that there was relationship between GDP and shipping trade, external debts payments and external reserves. Shipping is of great importance to Nigerian economy as identified in this study. One of the major challenges facing Nigeria at present is that it has no meaningful participation in the shipping industry as Nigeria depends on foreign vessels both for Exports and Imports trades.

In conclusion, Nigerian can gain a foothold in its shipping industry. The potential would be enormous, if shipping activities are properly harnessed given the few suggestions made in this study. Shipping will be ranked next to oil in foreign exchange earnings if not overtaken. Shipping is indispensable in economic growth and development of Nigeria with its attendant positive multiplier

\section{Recommendations}

The findings of this study bring to the limelight the needs for the following recommendations.

a. Government should and must do all it can to curtail foreign dominance and the repatriation of profit for a more sustainable economy as well as funding shipping services and operation (maritime) with needed 
finance.

b. Port facilities should be upgraded and modernized for quick discharge of consignments as a ship owners are more interested in timely turn-around of vessels for next engagement and avoid long-time and lay days.

c. Unnecessary delays, sharp practices and scam should be drastically reduced at the ports for shipment to move freely thereby making Just in Time (JIT) supply chain management to be effective in Nigeria.

d. Government should encourage production of exportable goods for maximum deployment of ships as most ships coming to Nigeria waters sail back on-ballast.

e. Investors should be encouraged to go into shipping trade with incentives like tax free holidays, government guaranteed loans etc.

\section{References}

Adeleye, J.O, Adeteye, O.S. and Adewuyi, M.O (2015): "Impact of International Trade on Economic Growth in Nigeria", International Journal of Financial Research, Vol. 6(3)

Christiana, O. I. and Matthew, B. O. (2013): "Has Maritime Transport Sector Impacted on The Growth of Nigeria's Economy?", Journal of Business and Economics, 4 (8), 722-736.

Durand, J.F. (2014): Wikipedia. [Online] Available at: http://en.wikipedia.org/wiki/Passengership [Accessed 24 March, 2018].

Ekpo, 2012: Impact of Shipping on Nigerian Economy: Implications for Sustainable Development Journal of Educational and Social Research Vol. 2 (7) October 2012.

Essien, E.A. (2002): "Nigeria's Economic Growth: Performance and Determinant" CBN Economic and Financial Review. Vol. 40(3).

Essien, E.A. and Bawa, E.N. (2007): "Explaining Growth: A Cross-Country Analysis of West African Monetary Zone (WAMZ)". CBN Economic and Financial Review. Vol. 40. setp.

Harris, R. (1995): Cointegration Analysis in Economic Modelling; New York, Prentice-Hall.

Ijirshar V. U., Joseph F. and Godoo M. (2016): The Relationship between External Debt and Economic Growth in Nigeria; International Journal of Economics \& Management Sciences2016, 6:1

Ma, S. (2011): "Lecture Notes, Handout and Slides on Logistics". Malmo World Maritime University.

Marin, P.H. (2011): Les Paquebots, ambassadeurs des mers. Paris: Gallimard.

Mukherjee, H. (2010): “Maritime Commercial Law". Unpublished Lecture Handout, World Maritime University Malmo, Sweden.

Muller, G. (2011): Integrated transport. Unpublished lecture handout, World Maritime University Malmo, Sweden.

Ofobrukweta, M.U. (2001), "Shipping and Forwarding Practice-Import", 'Fabolyn Nigeria Limited', Second edition, pp 1-3.

United Nations Conference on Trade and Development, (2007): "Review of Maritime Transport 2007”, Geneva: United Nations.

Usman, A. and Ibrahim, W. (2010): "External Reserve holdings in Nigeria: implications for investment, inflation and exchange rate", Journal of Economics and International Finance Vol. 2(9), pp. 183-189, ISSN $2006-9812$.

Vasilopoulos, D. (2013): "Naval Art (in Greek)". 1 1st edition, Thessaloniki: Academy of Merchant Marine of Macedonia.

Woodford, M. and Smith, C. (2000): “Economic Development (10 ${ }^{\text {th }}$ edition) New York, Addison Wesley”. 